\title{
TOTAL MERCURY DISTRIBUTION IN DIFFERENT FISH SPECIES REPRESENTING DIFFERENT TROPHIC LEVELS FROM THE ATLANTIC COAST OF GHANA
}

\author{
R. B. Voegborlo and A. A. Adimado \\ Chemistry Department, \\ Kwame Nkrumah University of Science \& Technology, Kumasi, Ghana
}

\begin{abstract}
Concentrations of total mercury ( $\mathrm{Hg}$ ) were measured in the edible muscle tissues of different fish species representing different trophic levels from the Atlantic Coast of Ghana using Cold Vapour Atomic Absorption Spectrophotometry (CVAAS). Mercury concentrations were generally found to increase with trophic levels. The concentrations of the metal (Hg) were highest (mean $=0.093 \mu \mathrm{g} \mathrm{g}^{-1}$ ) in high trophic level predatory fish, followed by middle trophic level predatory fish (mean=0.063 $\mu \mathrm{g} \mathrm{g}^{-1}$ ) and low trophic level fish (mean=0.047 $\mathrm{gg} \mathrm{g}^{-1}$ ). However the differences were not significant at the 0.05 level according to ANOVA. All fish species analysed in this study had total mercury concentrations (range: 0.001-0.278 $\mathrm{gg} \mathrm{g}^{-1}$ ) less than the FAO/WHO limit of $0.5 \mu \mathrm{g} \mathrm{g}^{-1}$ wet weight. The low concentrations of mercury in the fish species obtained in this study do not appear to contribute any significant mercury exposure to the general population; and suggest a relatively clean marine environment that has not yet been significantly impacted by mercury contamination probably due to minimal industrial activity in the region.
\end{abstract}

Keywords: Mercury; Fish; Atlantic Coast; Ghana; Trophic level

\section{INTRODUCTION}

The tremendous increase in mercury $(\mathrm{Hg})$ production and use in this century, and the availability of many soluble species of mercury have resulted to an extent in mercury contamination virtually world-wide and widespread in our environment. Hg travels easily through different environmental media, in a variety of chemical forms including its volatile form over long distances leading to global pollution. Industrialization and increasing population as a result of rapid urbanization, have also contributed to considerable discharge of domestic wastewater and industrial effluents into the sea contaminating the coastal waters. Such anthropogenic pollutants are the main sources of heavy metal contaminants in the ocean (Gibbs and Miskiewicz, 1995; EPA, 1997). The burning of coal and oil, and the use of mercury compounds as slimicides and as antifungal agents in the paper and pulp industry and in agriculture have contributed further to the release of mercury into the environment.

Moreover, in the marine environment, mercury is potentially accumulated in organisms and 


\section{Voegborlo and Adimado}

sediments, and subsequently transferred to man through the food chain (Rodgers, 1994; Lodenius and Malm, 1998; Mason, 2001). It is therefore important to determine the chemical quality of the marine organisms, particularly the levels of the toxic elements such as mercury in edible fish as a step towards the evaluation of the possible risk to human health from fish consumption. Consumption of contaminated fish (and other aquatic organisms) is the major route by which mercury enters human and wildlife food chains (Eisler, 1987; Clarkson, 1990).

Extensive surveys have therefore been carried out in a number of countries to evaluate the presence of mercury in the aquatic biota including fish, which can often be considered as an indicator of aquatic pollution (Bahnick and Sauer, 1994; Nixon et al., 1994; Mathieson and McLusky, 1995; Rolfhus and Fitzgerald, 1995; Monteiro et al., 1996; Nakagawa et al., 1997; Lacerda et al., 2000; Storelli et al., 2002; Love et al., 2003; Storelli et al., 2003; Voegborlo et al., 2004). The level of mercury found in a fish is related to the level of mercury in its aquatic environment and its place in the food chain (Monteiro et al., 1996). Apart from that, mercury also biomagnifies through the food chain; so large predatory fish species tend to have higher levels than non-predatory fish or species at lower levels in the food chain (Bloom, 1992; USEPA, 1997). It is methylmercury that is of special concern, as this is the form that is easily absorbed in living tissues and is known to bioaccumulate and biomagnify in animals and humans. Nearly all mercury that bioaccumulates in fish is methylmercury (EPA 2001). Methylmercury is produced in the aquatic environment by conversion of inorganic mercury from in situ production by natural bacteria under anoxic conditions (WHO, 1990)

Despite the considerable global concern about mercury contamination of commercial and recreational fishery products, there is paucity of information on mercury in fish from the coastal waters of Ghana. This study seeks to relate total mercury concentrations in different species of fish from the coastal waters of Ghana to their trophic levels in the Atlantic Ocean.

\section{MATERIALS AND METHODS}

Sampling and Sample Preparation

The fish species were collected from random commercial catches landed at a local fishing port in James Town and the Tema Fishing Harbour both in the Greater Accra Region of Ghana. Samples were obtained in three batches, depending on the species available for sale. Samples obtained were therefore reflective of species meant for consumption. A total of one hundred and nineteen samples (119) covering thirty-one (31) different species were obtained. The samples were sorted by species, placed in clean plastic bags and stored on ice in an ice chest. The samples were then transported to the laboratory, identified and kept in a freezer at $20^{\circ} \mathrm{C}$ prior to preparation for chemical analysis. The samples were washed with distilled water, dried in tissue paper and the length and body weight of each were determined after defrosting in the laboratory. A portion of the edible muscle tissue was removed from the dorsal part of each fish, homogenized and stored in clean-capped glass vials and kept in a freezer until analysis.

\section{Digestion procedure}

The fish samples were digested for total mercury determination by an open flask procedure developed at the National Institute for Minamata Disease (NIMD) in Japan by Akagi and Nishimura (1991). The accuracy of this method has been verified at NIMD through interlaboratory comparison exercises (Malm et al., 1995) and by participating in the analyses of Certified Reference Materials (CRMs) (e.g. IAEA 085, 086 and 142) supplied by the International Atomic Energy Agency (IAEA). The method involved weighing about $0.5 \mathrm{~g}$ of homogenized fish sample into $50 \mathrm{ml}$ volumetric digestion flask. One (1) $\mathrm{ml} \mathrm{H}_{2} \mathrm{O}, 2 \mathrm{ml} \mathrm{HNO}: \mathrm{HClO}_{3}$ (1:1) and $5 \mathrm{ml} \mathrm{H}_{2} \mathrm{SO}_{4}$ was then added in turn. The mixture was heated at a temperature of $200{ }^{\circ} \mathrm{C}$ for $30 \mathrm{~min}$. The sample solution was cooled and diluted to $50 \mathrm{ml}$ with double distilled water. A blank and standard solution digests using 25,50 and $100 \mathrm{ml}$ of $1 \mathrm{mg} \mathrm{ml}^{-1}$ standard $\mathrm{Hg}$ solution were subjected to the same treatment. 
The concentrations of the standard solution digests obtained were $0.5,1.0$ and $2.0 \mathrm{ng} \mathrm{ml}^{-1}$.

\section{Determination of mercury}

Determination of mercury in all the digests was carried out by cold vapour atomic absorption spectrophotometry using an Automatic Mercury Analyzer Model HG-5000 (Sanso Seisakusho Co., Ltd, Japan) developed at NIMD. The analyzer is an instrument designed specifically for the measurement of mercury using the cold vapour technique. It makes use of the batch mercury cold vapour generation system. The analyzer consists of an air circulation pump, a reaction vessel, $\mathrm{SnCl}_{2}$ dispenser, an acidic gas trap and a four- way stop-cock with tygon tubes to which is attached a ball valve. The operations of the ball valve and the air circulation pump are controlled by a microprocessor. During the determination, a known volume of the sample solution normally $5 \mathrm{ml}$ is introduced into the reaction vessel using a micropipette $(1-5 \mathrm{ml})$. The reaction vessel is immediately stoppered tightly and $0.5 \mathrm{ml}$ of $10 \%(\mathrm{w} /$ v) $\mathrm{SnCl}_{2} .2 \mathrm{H}_{2} \mathrm{O}$ in $1 \mathrm{M} \mathrm{HCl}$ is added from a dispenser for the reduction reaction. During this time, air is circulated through the four-way stopcock to allow the mercury vapour to come to equilibrium and the acidic gases produced by the reaction also swept into the sodium hydroxide solution. After 30 seconds the four-way stopcock is rotated through $90^{\circ}$ and the mercury vapour is swept into the absorption cell. Response was recorded on the strip chart recorder as a very sharp peak. Peak heights were used for computations. Standards used for calibration of the analyzer included solutions containing 0.0, 0.5, 1.0 and $2.0 \mathrm{ng} \mathrm{Hg} \mathrm{ml}^{-1}$.

For quality assurance blanks and duplicates were part of all analytical runs, as were predigestion spikes and post-digestion spikes. Detection limits, precision and accuracy of the analyses were determined by repeated analyses of some samples and certified reference material.

\section{RESULTS AND DISCUSSION}

Total mercury concentrations in the muscle tissue of different fish species were determined using a rapid, sensitive and accurate procedure developed at the National Institute for Minamata Disease (NIMD) in Japan by Akagi and Nishimura (1991). Analytical and matrix spike recoveries of the procedure were between $96 \%$ and $110 \%$ with coefficient of variation between $2 \%$ and $7 \%$. Detection limit, based on three standard deviations of sample blank measurements was $0.5 \mathrm{ng} \mathrm{Hg} \mathrm{g}{ }^{-1}$. Precision and accuracy of the analytical procedure were evaluated by repeated analyses of samples and Certified Reference Material (CRM). The precision of the overall procedure yielded results, which agreed to within $5 \%$. The validity of the method has been proved by the agreement between values obtained for the measured $\left(4.60-4.72 \mu \mathrm{g} \mathrm{g}^{-1}\right)$ and the certified $\left(4.15-4.79 \mu \mathrm{g} \mathrm{g}^{-1}\right)$ concentrations in Certified Reference Material (CRM), (Dogfish muscle, DORM-2) from the National Research Council of Canada (NRC) for total mercury. The results from the analysis were all within the $95 \%$ confidence level.

Results of total mercury in fish from the coastal waters of Ghana, which is part of the Atlantic Ocean, are presented in Table 1. The concentration of mercury in the edible muscle tissue of all the fish tested ranged from 0.001 to 0.278 $\mu \mathrm{g} \mathrm{g}^{-1}$. The results indicate that the mercury content in the samples studied depends on the fish species and the concentrations showed marked variations. Not all the factors responsible for these variations are understood but it is generally realized that the species of fish, the geographical location, and the age and/or weight of the fish are important. The highest values of mercury are usually seen in those fish at the end of a long food chain such as the large carnivorous species. Fish species from the Atlantic Ocean have been categorized into numerical trophic levels during the Trophic Analysis of the Atlantic Ocean where the Top Predators were assigned a numerical value of 5 and above; between the numerical values 4.00 and 4.99 fish are classified as High level carnivores; fish with numerical values between 3.00 and 3.99 are classified as Middle level carnivores while fish with values between 2.00 and 
4 Voegborlo and Adimado

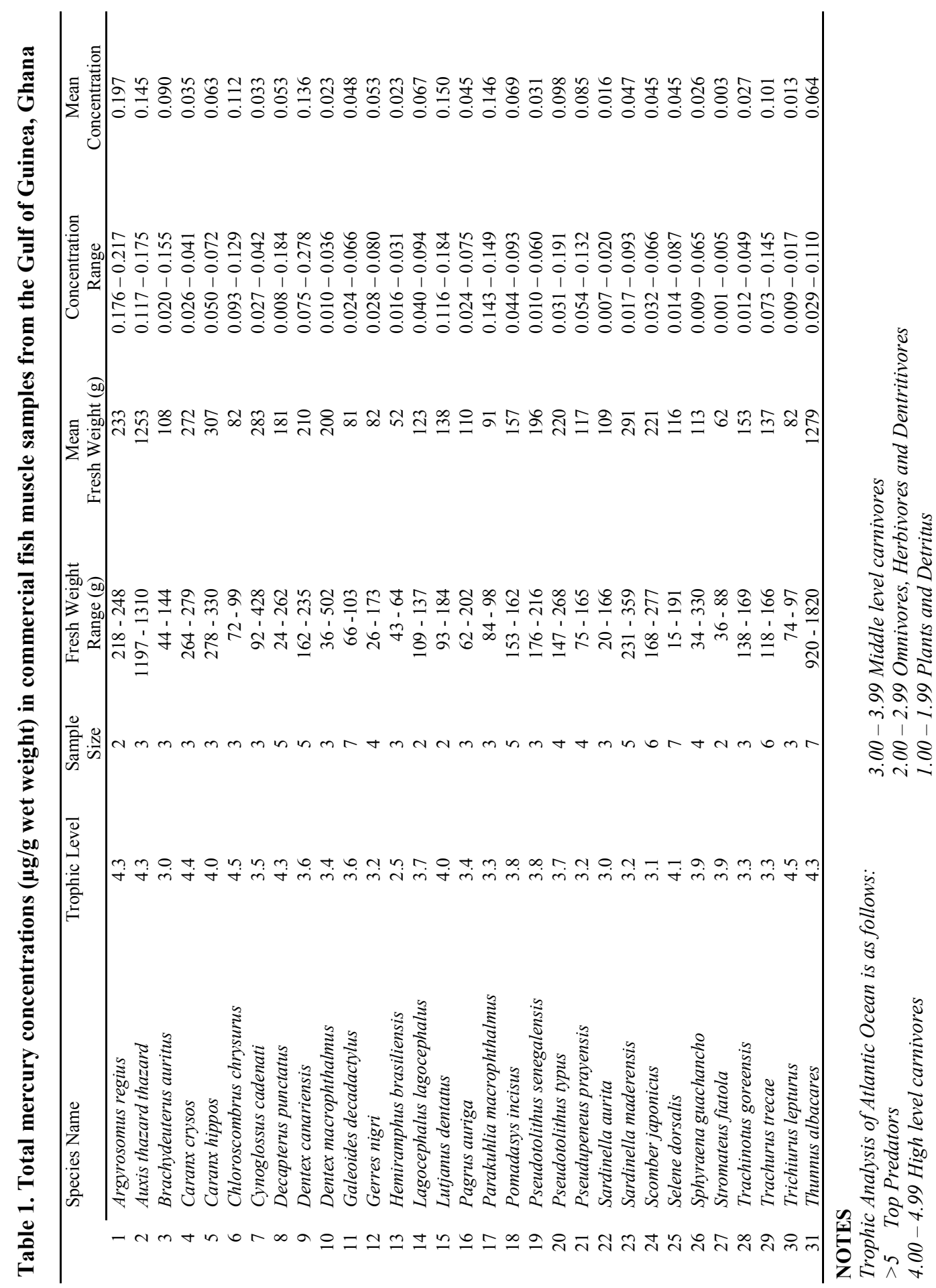

Journal of Science and Technology ㄷN KNST April 2010 
2.99 are classified as omnivores, herbivores or dentritivores (Froese and Pauly, 2009). The numerical trophic level value for each specie of fish analysed in this study was obtained from the database of Atlantic Ocean fish and indicated in Table 1. Out of the thirty-one species analysed, one of them namely Hemiramphus brasiliensis is omnivorous and at trophic level of 2.5 according to the trophic analysis of the Atlantic Ocean. The other thirty species are carnivorous. Twenty of them are middle level carnivores at trophic level between 3.0 and 3.99; and the other ten species are High level carnivores with numerical trophic values between 4.0 and 4.99. These include Auxis thazard thazard, Thunnus albacares, Caranx cryosis, Caranx hippos and Selene dorsalis. Figure 1 provides mean mercury concentrations for various fish species within each of the three trophic level groups. In general mercury concentrations show an increase in concentrations with increase in trophic level. Mercury concentrations were generally highest (mean $=0.093 \mu \mathrm{g}$ $\mathrm{g}^{-1}$ ) in high trophic level predatory fish, for example the highest mean mercury concentration $\left(0.197 \mu \mathrm{g} \mathrm{g}^{-1}\right)$ was found in Argyrosomus regius which is a high level carnivore with numerical trophic level 4.3 , followed by middle trophic level predatory fish (mean $=0.063 \mu \mathrm{g} \mathrm{g}^{-}$ $\left.{ }^{1}\right)$. In general, lower mercury concentrations were seen in low trophic level fish (mean=0.047 $\mu \mathrm{g} \mathrm{g}^{-1}$ ). Only one fish specie namely Hemiramphus brasiliensis in the low trophic level group was analysed in this study. However when mean mercury concentrations and the numerical trophic levels of the fish species were subjected to correlation analysis, no significant correlation was observed $\left(r^{2}=0.0479\right)$. Mercury levels in fish have also been reported to be related to the age/size of fish. Positive relationship between fish mercury concentration, weight and length within an individual water body has been documented. Good correlation normally existed among carnivorous species while herbivorous species normally show poor correlation. This observation was reported for tuna which is a carnivore (Voegborlo et al., 2006). As noted, elevated levels of mercury have been recorded for some species from each of the three trophic levels which may be attributed to size-effect of mercury. In this study, the size composition of the fish samples varied substantially. Thus to reduce the effect of variable size composition of the samples, mercury concentration was normalized by dividing the mean concentration with the mean fresh weight of each fish specie. Similar to the earlier observation, the normalized concentrations of mercury showed a similar trend and were not significantly correlated with the trophic level of the fish samples $\left(r^{2}=0.004\right)$ suggesting that weight did not significantly affect mercury accumulation in the fish samples tested.

Mercury concentration detected in all the fish samples $\left(0.001\right.$ to $\left.0.278 \mu \mathrm{g} \mathrm{g}^{-1}\right)$ are all below the $0.5 \mu \mathrm{g} \mathrm{g}^{-1}$ wet weight limit recommended by the FAO/WHO (1972) and adopted by many countries (CIFA, 1992). The concentration of mercury in fish has been the subject of intense study in recent years and the mercury content of marine fish has variously been reported. Reports indicated that mercury levels in most species of oceanic fish fall in the range of $0-0.5 \mu \mathrm{g}$ $\mathrm{g}^{-1}$ wet weight with most values close to 0.15 $\mu \mathrm{g} \mathrm{g}^{-1}$ wet weight (WHO, 1976). The most important exceptions to this rule include tuna fish whose values usually range from 0.2 to $1.5 \mu \mathrm{g}$ $\mathrm{g}^{-1}$ (FAO/WHO, 1972). Levels in skipjack, white tuna and yellow fin tuna caught in the Atlantic, Pacific and Indian Oceans ranged from 0 to $1.0 \mu \mathrm{g} \mathrm{g}^{-1}$ wet weight with most values ranging from 0.2 to $0.3 \mu \mathrm{g} \mathrm{g}^{-1}$ wet weight (WHO, 1976). The results of this study are either in agreement or lower than the levels reported by the other authors for marine fish in other areas of the world.

The main source of mercury to the marine environment is from wet and dry deposition from the atmosphere of inorganic mercury, from natural and anthropogenic, primarily combustion sources (WHO, 1976). Rivers that receive industrial effluents also contribute large amounts of mercury to the marine environment. Most of the mercury entering the marine environment then complexes with dissolved or par- 


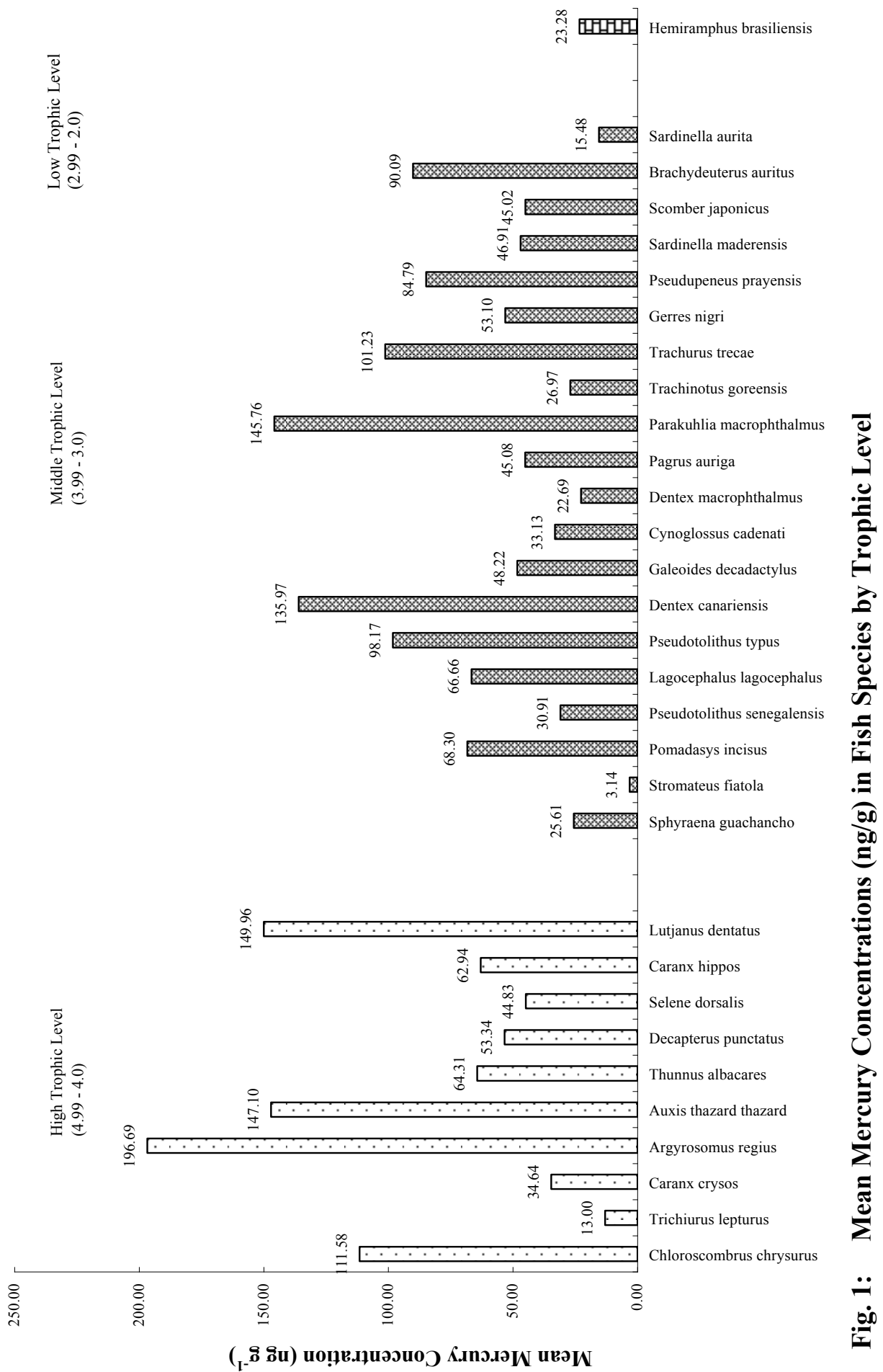

Journal of Science and Technology @ KNUST April 2010 
ticulate organic matter and may settle with it and accumulate in sediments. If the sediments or bottom water are hypoxic/anoxic, some of the inorganic mercury may be methylated by sulphate-reducing bacteria. Microbiallymediated mercury methylation also occurs in the oxygen-minimum layer of the ocean; this may be the source of methylmercury in the muscle tissues of large pelagic fish such as swordfish and tuna. That mercury in fish appears to be predominantly in the form of methylmercury has been confirmed by many publications (WHO, 1976; Bloom, 1992; Larsorsa and Gill, 1995; Andersen and Depledge, 1997; Al-Majeed and Preston, 2000). Swedish measurements of fish, summarized by a Swedish Expert Group (1971), indicated that virtually all of the mercury is present in the form of methylmercury compounds. These findings were confirmed for fish from the North American continent and for swordfish and tuna fish (WHO, 1976). Therefore, diet consisting particularly of fish, could be the main source of exposure to methylmercury in the general population. The results of this study provide a basis for assessment of human exposure of the coastal population to methylmercury. The generally low levels of mercury found in fish muscle from the Atlantic Coast of Ghana in this study (range $0.001-0.278 \mu \mathrm{g} \mathrm{g}^{-1}$ ) suggest that there is very little input or production of methylmercury in the marine environment. Since fish accumulate more methylmercury than inorganic mercury, the low total mercury levels in fish from this marine environment seems to indicate low concentrations of methylmercury in this part of the Gulf of Guinea. The concentrations of mercury in the fish samples obtained in this study are not high when compared to some other areas of the world and can be said to reflect background mercury concentrations that are even much lower than most published mercury concentrations in fish from non-polluted areas of the world (CIFA, 1992; Nixon et al., 1994). This corroborates the assertion that geographical location in addition to other factors like metabolic differences appears to be important with regards to the mercury content of fish; and this is illustrated by the analysis of fish from different locations (WHO, 1976). In a study of swordfish from six areas extending from Caribbean Sea to the Grand Banks, significant variations from one area to another were observed in average mercury levels (WHO, 1976). With regards to metabolic differences, variations in mercury content in different species of benthopelagic fish were observed despite the fact that they had identical feeding habits and ecological requirements and were exposed to mercury in the same area for the same length of time (WHO, 1976).

\section{CONCLUSION}

The results of this study indicate that mean total mercury concentrations in fish increase with increase in trophic level of fish though not significantly. All the samples obtained from the Ghanaian coastal waters of the Atlantic Ocean and analysed for mercury had concentrations below the WHO/FAO recommended limit. The low concentrations of mercury in the fish species obtained in this study suggest a relatively clean marine environment that has not yet been significantly impacted by mercury contamination probably due to minimal industrial activity in the region.

\section{ACKNOWLEDGEMENTS}

The technical assistance of Selorm Eric Agorku of Chemistry Department, Kwame Nkrumah University of Science \& Technology is acknowledged. The technical assistance of the staff of NIMD to one of the authors (RBV) during his visit to the institute is highly acknowledged. Thanks to Mr. Munir Abdullah Dawood of Theoretical and Applied Biology Department, Faculty of Biosciences, Kwame Nkrumah University of Science \& Technology for identifying the fish species.

\section{REFERENCES}

Akagi, H. and Nishimura, H. (1991). Speciation of mercury in the environment In: Suzuki, T., Imura, N and Clarkson, T. W. (Editors), Advances in Mercury Toxicology, Plenum Press, USA. pp 53-76. 


\section{Voegborlo and Adimado}

Al-Majeed, N. B. and Preston, M. R. (2000). An assessment of the total and methyl mercury content of zooplankton and fish tissue collected from Kuwait territorial waters. Marine Pollution Bulletin 40, 298-307.

Andersen, J. L. and Depledge, M. H. (1997). A survey of total mercury and methylmercury in edible fish and invertebrates from Azorean waters. Marine Environmental Research 44, 331-350.

Bahnick, D. and Sauer, C. (1994). A national study of mercury contamination of fish. Chemosphere 29, 537-546.

Bloom, N. (1992). On the chemical form of mercury in edible fish and marine invertebrate tissue. Canadian Journal of Fisheries and Aquatic Sciences 49, 1010-1017.

Clarkson, T. W. (1990). Human health risks from methylmercury in fish. Environmental Toxicology and Chemistry 9, 957961

CIFA (Committee for Inland Fisheries of Africa), (1992). Report of the Third Session of the Working Party on Pollution and Fisheries. FAO Fisheries Report No 471. Food and Agriculture Organisation of the United Nations, Rome.

Eisler, R. (1987). Mercury hazards to fish, wildlife and invertebrates: a synoptic review. U.S. Fish and Wildlife Service Biological Report 85, 1-10

EPA, (1997). Mercury Study Report to Congress EPA-452/R-97-003, U.S. Environmental Protection Agency, Office of Air Quality Planning and Standards, and Office of Research and Development.

EPA (2001). Water Quality Criterion for the Protection of Human Health: Methylmercury, EPA-823-R-01-001, U.S. Environmental Protection Agency, Office of Water.

FAO/WHO (Food and Agriculture/World Health Organisation), (1972). Evaluation of certain food additives and the contami- nants mercury, cadmium and lead. WHO Technical Report Series No. 505. Geneva: WHO

Froese, R. and Pauly, D. (2009). Fish Base World Wide Web electronic publication www.fishbase.org version (10/2009).

Gibbs, P. J. and Miskiewicz, A. Z. (1995). Heavy metal in fish near a major primary treatment sewage plant outfall. Marine Pollution Bulletin 30, 667-674.

Lacerda, L. D., Paraquetti, H. H. M., Marins, R. V., Rezende, C. E., Zalmon, I. R., Gomes, M. P. and Farias, V. (2000). Mercury content in shark species from the SouthEastern Brazilian Coast. Revista Brasileira de Biologia 60, 571-576

Lasorsa, B. and Gill, S. A. (1995). The methylmercury to total mercury ratio in selected marine, freshwater, and terrestrial organisms. Water Air Soil Pollution 80, 905-913.

Lodenius, L. and Malm, O. (1998). Mercury in the Amazon. Reviews of Environmental Contamination and Toxicology. 152, 25-52

Love, J. L., Rush, G. M. and McGrath, H. (2003). Total mercury and methylmercury levels in some New Zealand commercial marine fish species. Food Additives and Contaminants 20,37-43

Malm, O., Branches, F. J. P., Akagi, H., Castro, M. B., Pfeiffer, W. C., Harada, M., Bastos, W. R. and Kato, H. (1995). Mercury and methylmercury in fish and human hair from the Tapajos river basin, Brazil. Science of the Total Environment 175, 141150.

Mason, R. P. (2001). The bioaccumulation of mercury, methylmercury and other toxic elements into pelagic and benthic organisms. In: Newman, M. C., Robert, M. H. and Hale, R. C. (Editors), Coastal and Estuarine Risk Assessment, CRC/Lewis Publ.

Mathieson, S. and McLusky, D. S. (1995). Inter -Species variation of mercury in skeletal muscle of five fish species from inshore 
waters of the firth of Clyde, Scotland. $M a$ rine Pollution Bulletin 30, 283-286.

Monteiro, L. R., Costa, V., Furness, R. W. and Santos, R. S. (1996). Mercury concentrations in prey fish indicate enhanced bioaccumulation in mesopelagic environments. Marine Ecology Progress Series 141, 2125.

Nakagawa, R., Yumita, Y. and Hiromoto, M. (1997). Total mercury intake from fish and shellfish by Japanese people. Chemosphere 35, 2909-2913.

Nixon E., Rowe A. and McLaughlin D. (1994). Mercury concentrations in fish from Irish Waters in 1993. Marine Environmental Series/94 Fisheries Leaflet 162, Department of the Marine, Dublin

Rodgers, D. W. (1994). You are what you eat and a little bit more: Bioenergetics-based models of methylmercury accumulation in fish revisited. In: Watras, C. J. and Huckabel, J. W. (Editors), Mercury Pollution: Integration and Synthesis. Lewis Publishers, NY, pp 427-439.

Rolfhus, K. R. and Fitzgerald, W. F. (1995). Linkage between atmospheric mercury deposition and the methylmercury content of marine fish. Water Air Soil Pollution 80, 291-297.

Storelli, M. M., Giacominelli-Stuffler, R. and Marcotrigiano, G. O. (2002). Total and methylmercury residues in cartilaginous fish from Mediterranean Sea. Marine Pollution Bulletin 44, 1354-1358.

Storelli, M. M., Stuffler, R. G., Storelli, A. and Marcotrigiano, G. O. (2003). Total mercury and methylmercury content in edible fish from the Mediterranean Sea. Journal of Food Protection 66, 300-303.
Swedish Expert Group (1971). Methylmercury in fish. A toxicological-epidemiological evaluation of risks. Nordisk Hygienisk Tidskrift 4, 19-364

USEPA (United States Environmental Protection Agency) (1997). Mercury Study Report to Congress, Volume III, Fate and Transport of Mercury in the Environment, Document \#EPA-452/R- 97-005.

Voegborlo, R. B., Akagi, H., Matsuyama, A., Adimado, A. A. and Ephraim, J. H. (2006). Total Mercury and Methylmercury Accumulation in the Muscle Tissue of Frigate (Auxis thazard thazard) and Yellow Fin (Thunnus albacares) Tuna from the Gulf of Guinea, Ghana. Bulletin of Environmental Contamination \& Toxicology., 76 (5): 840 - 847

Voegborlo, R. B., Baah, D. A., KwaansaAnsah, E. E., Adimado, A. A. and Ephraim, J. H. (2004). Mercury Concentrations in Fish Species from the Gulf of Guinea, Ghana. Bulletin of Environmental Contamination and Toxicology, 73, 1057-1064.

WHO (1976). Environmental Health Criteria I. Mercury. World Health Organisation, pp 131.

WHO (1990). Environmental Health Criteria 101. Methylmercury. World Health Organisation, pp 145 